\title{
Relationship between production, nematodes and "redness" in strawberries
}

\author{
Relação entre produção, nematoide e o sintoma de "vermelhão" em morangueiros
}

\author{
Paula Nogueira Curi ${ }^{I}$ Pedro Maranha Peche ${ }^{\mathrm{I}}$ Rafael Pio ${ }^{\mathrm{I}^{*}}$ \\ Csaignon Mariano Caproni ${ }^{I I I}$ Márcia Souza de Oliveira ${ }^{I I}$
}

\section{ABSTRACT}

In recent years "redness" has increasingly appeared in strawberry plants with leaves taking on a reddish color. No causal agent has been associated with plants. Since strawberries presented problems due to the incidence of nematodes, the purpose of this study was to look at the relationship between production, resistance to the Meloidogyne hapla nematode and the "redness" symptom in strawberry cultivars. Two experiments were performed, both with the 'Camino Real', 'Festival', 'Oso Grande', 'Albion' and 'Camarosa' cultivars. The first experiment was performed in the field, where the following were evaluated: strawberry production, fruit quality, macro and micronutrient contents in fruit and leaves, percentage of plant survival, incidence of nematodes, quantity of eggs in the roots and juveniles in the soil, and the incidence of Botrytis cinerea. In the second experiment, the strawberries were transplanted into pots and filled with pinus bark-based commercial substrate. Half the pots were inocculated with Meloidogyne hapla. Cultivars presented differences in fruit production and also in the incidence of "redness". Lowest performance in production was related to the high incidence of the nematode Meloidogyne hapla. 'Oso Grande' and 'Albion' presented nematode-resistant behavior. It was possible find a relationship between the incidence of the Meloidogyne hapla nematode, and the incidence of "redness" only 'Camino Real' cultivar.

Key words: Botrytis cinerea, Meloidogyne hapla, Fragaria ananassa.

\section{RESUMO}

Nos últimos anos, vem aumentando o aparecimento do "vermelhão" nos morangueiros, que ficam com as folhas avermelhadas. Nenhum agente causal foi associado às plantas. Devido aos plantios de morangueiros apresentarem problemas pela incidência de nematoide, o objetivo do presente trabalho foi verificar a relação entre produção, resistência ao nematoide Meloidogyne hapla e o sintoma de "vermelhão" em cultivares de morangueiro. Foram realizados dois experimentos, ambos com as cultivares 'Camino Real', 'Festival', 'Oso Grande', 'Albion' e 'Camarosa'. O primeiro experimento foi realizado a campo, onde se avaliaram a produção de morangos, qualidade dos frutos, teores de macro e micronutrientes em frutos e folhas, porcentagem de sobrevivência das plantas, incidência de nematoides, quantidade de ovos nas raizes e juvenis no solo e a incidencia de Botrytis cinerea. No segundo experimento, os morangueiros foram transplantados em vasos e preenchidos com substrato comercial a base de casca de pinus. Metade dos vasos foi inoculada com Meloidogyne hapla. As cultivares apresentaram diferenças na produção de frutos e também na incidência de "vermelhão". O menor desempenho produtivo relaciona-se com a alta incidencia de nematoide Meloidogyne hapla. 'Oso Grande' $e$ 'Albion' se comportaram como resistentes ao nematoide. Foi possivel relacionar a incidência de nematoide Meloidogyne hapla com a de "vermelhão" apenas na cultivar 'Camino Real'.

Palavras-chave: Botrytis cinerea, Meloidogyne hapla, Fragaria ananassa.

\section{INTRODUCTION}

Brazil is the second largest producer of strawberries (Fragaria ananassa) and the main region where they are produced in the country is the south of Minas Gerais where $90 \%$ of the production in that state is concentrated, with an annual production close to 85 thousand tons (CAPRONI et al., 2013). The main cultivars in Minas Gerais are 'Camino

\footnotetext{
'Programa de Pós-graduação em Fitotecnia, Departamento de Agricultura, Universidade Federal de Lavras (UFLA), Lavras, MG, Brasil. "Departamento de Agricultura, Universidade Federal de Lavras (UFLA), 37200-000, Lavras, MG, Brasil. E-mail: rafaelpio@dag.ufla.br. ${ }^{*}$ Correspondig author.

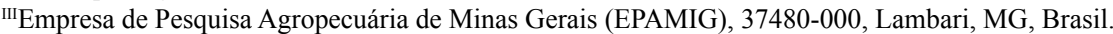
Received 04.29.15 Approved 02.22.16 Returned by the author 05.06.16 CR-2015-0621.R2
} 
Real', 'Oso Grande' and 'Albion', due to their good adaptation to the subtropical conditions in the region and the large fruit production (NUNES et al., 2013).

However, these cultivars have presented phytosanitary problems, mainly reduction of production cycle, due to the incidence of nematodes. Nematode Meloidogyne hapla insides on the strawberry plants and allows galls to form on the roots, when it is present in high populations in the soil, reducing the root volume and causing less growth and fruit production (NYOIKE et al., 2012). A control strategy would be to use genetic resistance which provides the lowest reproduction factor of Meloidogyne hapla (PINHEIRO et al., 2014).

In recent years "redness" has increasingly occurred in the cultivation of strawberries, especially in the south of the state of Minas Gerais. No pathogen or causal agent associated with the plants has been identified so far. Plants with "redness" have reddish older leaves, and in very extreme cases the plants die. Symptoms of "redness" can be caused by various nutritional deficiencies, phytotoxicity and injuries. In some plants with "redness", small galls typical of nematodes are observed. (HENZ, 2010). When genetic resistance is used to control Meloidogyne hapla and "redness", other characteristics must be evaluated in selecting the cultivars, such as production performance and incidence of gray mold. The objective was to look at the relationship between the production of strawberries of different strawberry plant cultivars, resistance to the nematode and the "redness" symptom.

\section{MATERIALS AND METHODS}

The study was divided into two experiments. The first in Pouso Alegre-MG, south of Minas Gerais, (Cwa, mesothermal or tropical altitude climate, with a dry winter and wet summer, according to the Köppen classification) and the second was performed in a greenhouse in LavrasMG (the climate is Cwb, mesothermal or tropical altitude, with a dry winter and mild and wet summer). Two experiments were performed:

\section{a) Experiment 1}

First experiment was set up on a $1.20 \mathrm{~m}$ broad and $0.30 \mathrm{~m}$ high bed. Soil was corrected and fertilized according to the needs of that culture (CAPRONI et al., 2013). Five cultivars , commercially important, were used in the south of Minas Gerais: 'Camino Real', 'Festival', 'Oso Grande', 'Albion' and 'Camarosa'. Fresh seedlings were imported from Patagonia, transplanted in April 2014, with a $0.30 x 0.40$ spacing. Cover ("mulching") was composed by black polyethylene film, and drip irrigation was used.

The experimental design was by randomized blocks, containing five treatments (cultivars), with six blocks and 32 seedlings per plot. Production variables evaluated were: number of fruits per plant, production $(\mathrm{g})$ and estimated productivity $(\mathrm{t}$ $\mathrm{ha}^{-1}$ ), evaluated from the end of May to October 2014. In each plot the fruits were picked and then counted and weighed with the help of a semi-analytic balance. At the end of the production cycle all the values of the number of fruit were added up, and all masses were recorded and thus the production per plant and estimated productivity were determined.

The following were counted monthly, between the months from May to October: percentage of plant survival (\%) obtained by division between the density of dead plants and number of living plants, the incidence of "redness" obtained by the division between the density of plants that presented typical symptoms of "redness", and the number of living plants, the quantity of Meloidogyne hapla nematode eggs in the roots and their juveniles in the soil. The nematodes from galls were differentiated through enzymatic phenotypes by electrophoresis (NYOIKE et al., 2012). The SCAR markers were validated for the Meloidogyne species associated with different strawberry plant cultivars.

The reproduction factor (RF) of nematodes in the cultivars was obtained by the division between final and initial population densities $(\mathrm{RF}=$ final population/initial population). Initial population was considered the inoculum extracted in June and, the final one, the eggs extracted in October. In order to evaluate the reaction regarding the susceptibility or resistance of each cultivar to Meloidogyne hapla, resistant plants were considered those with $\mathrm{RF}<1$ and susceptible plants those with RF $>1$ (PINHEIRO et al., 2014). The incidence of Botrytis cinerea in August was evaluated according to the presence of the symptoms in fruits of five cultivars, and a sample of 40 fruits per plot is collected randomly.

In August, when plants presented the maximum production, samples of 20 fruits per plot were taken on terephthalate polyethylene trays, placed in boxes with ice and transported to determine the physicochemical characteristics: length $(\mathrm{mm})$ and mean diameter $(\mathrm{mm})$ of fruits, mean mass of fruits $(\mathrm{g})$, soluble solids (SS), with a reading expressed in "Brix; titratable acidity (TA), obtained by titrating the samples with solutions of 
$\mathrm{NaOH} 0,1 \mathrm{~N}$, expressed in $\%$ of citric acid and fruit firmness $(\mathrm{N})$, using a penetrometer.

Nutritional analyses of leaves and fruits were performed on samples collected in September, month in which the strawberries have already reached the peak of fruit production in southern Minas Gerais. They were ground in a cooled mill at a 22,500rpm rotation, stored in a hermetically closed glass container, and protected from light at ambient temperature for the analyses of mineral composition. Nitrogen was determined by the semimicro-Kjeldahl method, phosphorus and boron by colorimetric methods, sulphur by turbidimetry, potassium by flame and emission photometry, and calcium, magnesium, copper, iron, manganese and zinc were determined by the atomic absorption spectrophotometry method.

\section{b) Experiment 2}

In the second experiment, the seedlings were transplanted in May, into $10 \mathrm{~L}$ pots with pinus-bark based commercial substrate. The design adopted was randomized blocks, with six blocks, six plants per plot and five strawberry cultivars used in the first experiment, with a total of 180 pots. Ninety pots were inoculated with Meloidogyne hapla and the rest not. In this experiment, it is not the cultivars that are compared, but inoculation and non inoculation with Meloidogyne hapla.

Inoculum of Meloidogyne hapla was obtained by multiplying it in tomato plants (Lycopersicon esculentum L.) of the 'Rutgers' cultivar. Eggs were extracted grinding the tomato roots in a blender. The suspensions were of 1,000 eggs and/or juveniles $\mathrm{ml}^{-1}$. Inculation was performed 30 days after the seedlings were planted by depositing $5 \mathrm{ml}$ of a suspension containing 9,000 eggs per plant ${ }^{-1}$ (PINHEIRO et al., 2014). After 60 days the incidence of "redness" (\%) was evaluated, and the final fresh mass of the root $(\mathrm{g})$ was obtained by removing root system of plants and weighing it with the help of a semi-analytic balance. Roots were separated, washed in water, fragmented and grounded. Quantity of Meloidogyne hapla eggs was read with an optical microscope.

After all analyses, the data were submitted to analysis of variance and measures compared using Tukey's test. Analyses were performed using the System for Analysis of Variance - SISVAR computer program.

\section{RESULTS AND DISCUSSION}

\section{a) Experiment 1}

The greatest number of fruit per plant and production was obtained with the "Oso Grande" cultivar (Table 1), which had an estimated productivity of $29.22 \mathrm{t} \mathrm{ha-1}$. This productivity is 16.49t ha $\mathrm{t}^{-1}$ higher than that obtained with 'Camino Real' and 17.04t ha' $\mathrm{ha}^{-1}$ compared to 'Camarosa'. Smallest production by plants of these two cultivars is associated with the results obtained by $\mathrm{COCCO}$ et al. (2012), who recorded $122.8 \mathrm{~g}$ per plant with cultivar 'Camino Real' and 203.8g with 'Camarosa', while in this study $212.20 \mathrm{~g}$ and $199.62 \mathrm{~g}$, were

Table 1 - Number of fruits per plant, production, estimated productivity, length (L) and mean diameter (D) of fruits, mean mass of fruits (M), soluble solids (SS, express in ${ }^{\circ}$ Brix), titratable acidity (TA) and firmness fruit strawberry cultivars in southern Minas Gerais State.

\begin{tabular}{|c|c|c|c|c|c|c|}
\hline Cultivar & \multicolumn{2}{|c|}{-------Number of fruits per plant ${ }^{(1)}$} & --Produc & plant $(g)^{(1)}-----$ & \multicolumn{2}{|c|}{----Estimated productivity $\left(\mathrm{t} \mathrm{ha}^{-1}\right)^{(1)}$---- } \\
\hline 'Camino Real' & \multicolumn{2}{|c|}{$18.2 \mathrm{c}$} & \multicolumn{2}{|c|}{$212.2 d$} & \multicolumn{2}{|c|}{$12.7 \mathrm{~d}$} \\
\hline 'Festival' & \multicolumn{2}{|c|}{$37.7 \mathrm{~b}$} & \multicolumn{2}{|c|}{$362.7 \mathrm{~b}$} & \multicolumn{2}{|c|}{$21.7 \mathrm{~b}$} \\
\hline 'Oso Grande' & \multicolumn{2}{|c|}{$47.3 \mathrm{a}$} & \multicolumn{2}{|c|}{$487.0 \mathrm{a}$} & \multicolumn{2}{|c|}{$29.2 \mathrm{a}$} \\
\hline 'Albion' & \multicolumn{2}{|c|}{$25.6 \mathrm{c}$} & \multicolumn{2}{|c|}{$305.6 \mathrm{c}$} & \multicolumn{2}{|c|}{$18.3 \mathrm{c}$} \\
\hline 'Camarosa' & \multicolumn{2}{|c|}{$21.2 \mathrm{c}$} & \multicolumn{2}{|c|}{$199.6 \mathrm{~d}$} & \multicolumn{2}{|c|}{$12.1 \mathrm{~d}$} \\
\hline CV (\%) & \multicolumn{2}{|c|}{16.1} & \multicolumn{2}{|c|}{9.7} & \multicolumn{2}{|c|}{9.7} \\
\hline Cultivar & $\mathrm{L}(\mathrm{mm})^{(1)}$ & $\mathrm{D}(\mathrm{mm})^{(1)}$ & $M(g)^{(1)}$ & $\mathrm{SS}\left({ }^{\circ} \mathrm{Brix}\right){ }^{(1)}$ & TA $\left(g 100 g^{-1}\right)^{(1)}$ & Firmness $(\mathrm{N})^{(1)}$ \\
\hline 'Camino Real' & $45.1 d$ & $39.3 b$ & $25.1 \mathrm{c}$ & $7.4 \mathrm{~d}$ & $0.5 b$ & $15.0 \mathrm{a}$ \\
\hline 'Festival' & $54.2 \mathrm{~b}$ & $38.8 \mathrm{~b}$ & $26.9 \mathrm{~b}$ & $6.7 \mathrm{~d}$ & $0.4 \mathrm{~b}$ & $13.8 \mathrm{ab}$ \\
\hline 'Oso Grande' & $47.6 \mathrm{c}$ & $34.7 \mathrm{c}$ & $21.0 \mathrm{~d}$ & $10.2 \mathrm{a}$ & $0.5 \mathrm{~b}$ & $10.4 \mathrm{~b}$ \\
\hline 'Albion' & $61.2 \mathrm{a}$ & $40.9 \mathrm{a}$ & $33.5 \mathrm{a}$ & $9.2 \mathrm{~b}$ & $0.6 \mathrm{a}$ & $13.0 \mathrm{ab}$ \\
\hline 'Camarosa' & $46.7 \mathrm{c}$ & $32.5 \mathrm{~d}$ & $21.1 \mathrm{~d}$ & $8.3 \mathrm{c}$ & $0.6 \mathrm{a}$ & $12.9 \mathrm{ab}$ \\
\hline $\mathrm{CV}(\%)$ & 1.3 & 1.3 & 1.6 & 6.0 & 7.7 & 15.5 \\
\hline
\end{tabular}

${ }^{(1)}$ Means followed by the same letter in the column do not differ by the Scott-Knott test $(\mathrm{P} \leq 0.05)$.

Ciência Rural, v.46, n.8, ago, 2016. 
recorded in both cultivars, respectively. This lower production obtained with the Camarosa 'Camino Real' cultivar may be due to nematodes, since there was a large quantity of eggs in the roots (Table 2).

In the case of the 'Albion', cultivar, the estimated productivity of $18.34 \mathrm{tha}^{-1}$ may be explained by the larger size and fresh mass obtained, superior to the others (Table 1). Comparing the number of fruits obtained from 'Albio' to 'Oso Grande', there was a production of almost 22 fruits less (Table 1). Furthermore, the fresh mass of the fruits recorded with 'Albion' was $12.5 \mathrm{~g}$ superior to the mean mass of the 'Oso Grande' fruits. MIRANDA et al. (2014) reported that 'Oso Grande' is more productive than
'Albion', but, considering the large size of its fruits, production is relatively smaller. Larger soluble solids content and a higher ratio of soluble solids and acidity were found in 'Oso Grande', a fundamental characteristic in fruit that are to be sold as fresh fruit, but they were less firm (Table 1).

In monthly assessments of survival percentage of plants there were not found death of plants in the first two months of evaluation, i.e., after 30 and 60 days after planting. In July only $61.4 \%$ of the 'Camino Real' cultivar remained alive; in October, only $20 \%$ of plants that grow survived (Table 2 ). It is noteworthy that there was mortality in plants of other cultivars, but in smaller quantities.

Table 2 - Percentage of plant survival (\%), incidence of "redness" (\%),quantity of Meloidogyne hapla nematode eggs in the roots and juveniles Meloidogyne hapla in the soil in strawberry cultivars in southern Minas Gerais states, between the months from May to October.

\begin{tabular}{|c|c|c|c|c|c|c|}
\hline Cultivar & May & June & July & August & September & October \\
\hline \multicolumn{7}{|c|}{ 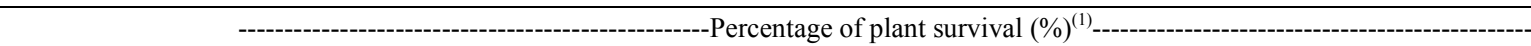 } \\
\hline 'Camino Real' & $100.0^{\mathrm{ns}}$ & $100.0^{\mathrm{ns}}$ & $61.4 \mathrm{~b}$ & $55.3 \mathrm{~b}$ & $28.9 b$ & $20.0 \mathrm{~b}$ \\
\hline 'Festival' & 100.0 & 100.0 & $90.2 \mathrm{a}$ & $90.2 \mathrm{a}$ & $90.2 \mathrm{a}$ & $86.0 \mathrm{a}$ \\
\hline 'Oso Grande' & 100.0 & 100.0 & $96.3 \mathrm{a}$ & $96.3 \mathrm{a}$ & $96.3 \mathrm{a}$ & $94.9 \mathrm{a}$ \\
\hline ‘Albion' & 100.0 & 100.0 & $87.1 \mathrm{a}$ & $87.1 \mathrm{a}$ & $84.0 \mathrm{a}$ & $83.0 \mathrm{a}$ \\
\hline 'Camarosa' & 100.0 & 100.0 & $82.5 \mathrm{a}$ & $82.5 \mathrm{a}$ & $96.9 \mathrm{a}$ & $91.8 \mathrm{a}$ \\
\hline CV (\%) month & \multicolumn{6}{|c|}{9.85} \\
\hline $\mathrm{CV}(\%)$ cultivar & \multicolumn{6}{|c|}{11.02} \\
\hline & & --- & Incidence & ss" $(\%)^{(1)}-$ & & \\
\hline 'Camino Real' & $9.1^{\mathrm{ns}}$ & $26.0 \mathrm{a}$ & $62.9 \mathrm{a}$ & $34.3 \mathrm{a}$ & $44.9 \mathrm{a}$ & $42.0 \mathrm{a}$ \\
\hline 'Festival' & 0.0 & $4.3 \mathrm{c}$ & $10.6 \mathrm{~b}$ & $7.5 \mathrm{bc}$ & $11.9 \mathrm{bc}$ & $3.0 \mathrm{~b}$ \\
\hline 'Oso Grande' & 0.0 & $0.0 \mathrm{c}$ & $0.0 \mathrm{c}$ & $0.0 \mathrm{c}$ & $0.9 \mathrm{c}$ & $1.3 b$ \\
\hline 'Albion' & 0.0 & $4.1 \mathrm{c}$ & $13.9 \mathrm{~b}$ & $4.5 \mathrm{bc}$ & $16.5 b$ & $3.8 \mathrm{~b}$ \\
\hline 'Camarosa' & 0.0 & $15.8 \mathrm{~b}$ & $24.0 \mathrm{~b}$ & $17.4 \mathrm{~b}$ & $27.0 \mathrm{~b}$ & $8.3 b$ \\
\hline CV (\%) month & \multicolumn{6}{|c|}{27.40} \\
\hline \multirow[t]{2}{*}{ CV (\%) cultivar } & \multicolumn{6}{|c|}{32.41} \\
\hline & \multicolumn{6}{|c|}{----Quantity of Meloidogyne hapla nematode eggs in the roots ${ }^{(1)}$} \\
\hline 'Camino Real' & $0.0^{\mathrm{ns}}$ & $34.6 \mathrm{c}$ & $4,094.6 \mathrm{a}$ & $1,618.3 b$ & $14,457.3 \mathrm{a}$ & $10,590.3 \mathrm{a}$ \\
\hline 'Festival' & 0.0 & $86.6 \mathrm{c}$ & $487.6 \mathrm{c}$ & $288.6 \mathrm{c}$ & $2,022.0 \mathrm{c}$ & $3,741.0 \mathrm{~b}$ \\
\hline 'Oso Grande' & 0.0 & $2,254.0 \mathrm{a}$ & $4,502.6 \mathrm{a}$ & $9,697.3 \mathrm{a}$ & $6,698.0 \mathrm{~b}$ & $566.6 \mathrm{c}$ \\
\hline 'Albion' & 0.0 & $800.0 \mathrm{~b}$ & $2,235.3 b$ & $4,937.3 \mathrm{a}$ & $7,202.0 \mathrm{~b}$ & $670.0 \mathrm{c}$ \\
\hline 'Camarosa' & 0.0 & $685.3 b$ & $816.6 \mathrm{c}$ & $372.6 \mathrm{c}$ & $811.3 \mathrm{~d}$ & $1,069.6 b$ \\
\hline $\mathrm{CV}(\%)$ month & \multicolumn{6}{|c|}{35.75} \\
\hline \multirow[t]{2}{*}{ CV (\%) cultivar } & \multicolumn{6}{|c|}{36.78} \\
\hline & & 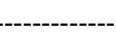 & ----Juveni & soil $^{(1)}-\mathbf{-}^{-}$ & -----. & \\
\hline 'Camino Real' & $1,084.6 \mathrm{a}$ & $608.6 \mathrm{a}$ & $186.6^{\mathrm{ns}}$ & $463.3^{\mathrm{ns}}$ & $244.6 b$ & $963.3 \mathrm{a}$ \\
\hline 'Festival' & $249.3 b$ & $112.0 \mathrm{~b}$ & 168.0 & 380.6 & $254.0 \mathrm{~b}$ & $364.0 \mathrm{~b}$ \\
\hline 'Oso Grande’ & $485.3 b$ & $492.6 \mathrm{a}$ & 138.6 & 327.3 & $793.3 \mathrm{a}$ & $1,141.0 \mathrm{a}$ \\
\hline ‘Albion’ & $298.0 \mathrm{~b}$ & $561.3 \mathrm{a}$ & 120.6 & 282.0 & $710.0 \mathrm{a}$ & $473.6 \mathrm{~b}$ \\
\hline 'Camarosa' & $440.0 \mathrm{~b}$ & $352.6 \mathrm{ab}$ & 226.6 & 226.6 & $561.3 \mathrm{ab}$ & $946.3 \mathrm{a}$ \\
\hline $\mathrm{CV}(\%)$ month & & & & 38.20 & & \\
\hline $\mathrm{CV}(\%)$ cultivar & & & & 27.15 & & \\
\hline
\end{tabular}

${ }^{(1)}$ Means followed by the same letter in the column do not differ by the Scott-Knott test $(\mathrm{P} \leq 0.05)$. ns - not significant. 
The 'Camino Real' plants had a higher incidence of "redness" (Table 2). For this reason, in comparative analysis of the macro and micronutrients recorded in this cultivar it can be seen lower levels of potassium in fruits and leaves and iron in leaf tissue (Table 3). Faced with high incidence of "redness" in the "Camino Real' cultivar (Table 2) and consequently nutritional deficiency of potassium and iron nutrients (Table 3 ), the productivity of this cultivar was low (Table 1).

ANTUNES et al. (2014) pointed out that the potassium and iron contents in the 'Camino Real' fruits are lower than in the other cultivars. Plants with a potassium deficiency present chlorosis in the old leaves (RODAS, 2008). Furthermore, iron deficiency makes the leaves yellow and with burned edges. According to the same author, nitrogen deficiency causes a reddish color in leaves, which evolve to necrosis. It is assumed that the "redness" was associated with nitrogen deficiency; however, contents in the 'Camino Real' leaves are high (Table 3).

When the nematode eggs in the roots were quantified in August, the larger quantities were found in the 'Oso Grande' and 'Albion' cultivars, but they diminished sharply in October (Table 2). Moreover, in the last two months larger quantities of eggs were found in 'Camino Real'. But it was also noted that there was an increase the number of eggs over months in 'Camarosa' and 'Festival' cultivars. Therefore, these oscillations must be related to genetic factors. However, in quantifying the juveniles in soil, there was great variation over the months, but in the end higher values were found in soils where 'Camino Real', 'Oso Grande' and 'Camarosa' had been planted.

\section{b) Experiment 2}

Only 'Oso Grande' and 'Albion' cultivars were resistant, because they had a lower response factor than 1.0 (Table 4). This reinforces the hypothesis of nematode eggs oscillations in the soil over the months of evaluation, since these two cultivars were classified as resistant and the three others as susceptibility.

The only cultivar that shows the relationship between the low productions (Table 1), susceptibility to nematodes (Table 4), high incidence of "redness" (Table 2) and deficiency symptoms (Table 3) was 'Camino Real ', which agrees with HENZ (2010), who said that in this cultivar there is a high occurrence of "redness". This is confirmed when comparing the vessels that received the inoculation with the vessels that were not inoculated with nematode, because the symptom "redness" was only present in plants with inoculated vessels (Table 5).

However, with the results obtained with the other cultivars, it cannot be confirmedthat low production and incidence of nematodes are

Table 3 - Levels of macro and micronutrients: nitrogen (N\%), phosphorus ( $\mathrm{P} \%)$, potassium $(\mathrm{K} \%)$, calcium $(\mathrm{Ca} \%)$, magnesium $(\mathrm{Mg} \%)$, sulphur (S\%), boron (B ppm), copper (Co ppm), manganese (Mn ppm), zinc (Zn ppm) and iron (I ppm) in fruits and leaves in strawberry cultivars in southern Minas Gerais states.

\begin{tabular}{|c|c|c|c|c|c|c|c|c|c|c|c|}
\hline Cultivar & $\mathrm{N}^{(1)}$ & $\mathrm{P}^{(1)}$ & $\mathrm{K}^{(1)}$ & $\mathrm{Ca}^{(1)}$ & $\mathrm{Mg}^{(1)}$ & $\mathrm{S}^{(1)}$ & $\mathrm{B}^{(1)}$ & $\mathrm{Co}^{(1)}$ & $\mathrm{Mn}^{(1)}$ & $\mathrm{Zn}^{(1)}$ & $\mathrm{I}^{(1)}$ \\
\hline & & & & & & Fruit & 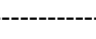 & & & 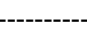 & -------- \\
\hline 'Camino Real' & $0.9 \mathrm{~b}$ & $0.1^{\mathrm{ns}}$ & $1.1 \mathrm{c}$ & $0.2 \mathrm{a}$ & $0.1^{\mathrm{ns}}$ & $0.2 \mathrm{a}$ & $6.7 d$ & $2.7 \mathrm{~b}$ & $11.5 b$ & $10.6 b$ & $133.6 \mathrm{c}$ \\
\hline 'Festival' & $0.9 \mathrm{~b}$ & 0.1 & $1.4 \mathrm{~b}$ & $0.1 b$ & 0.1 & $0.1 \mathrm{~b}$ & $10.7 b$ & $2.7 \mathrm{~b}$ & $10.6 \mathrm{c}$ & $13.0 \mathrm{a}$ & $122.7 \mathrm{~d}$ \\
\hline 'Oso Grande' & $0.9 \mathrm{~b}$ & 0.1 & $1.6 \mathrm{ab}$ & $0.1 \mathrm{~b}$ & 0.1 & $0.2 \mathrm{a}$ & $12.7 \mathrm{ab}$ & $3.4 \mathrm{a}$ & $11.5 b$ & $9.1 \mathrm{c}$ & $134.2 \mathrm{~b}$ \\
\hline ‘Álbion’ & $0.9 \mathrm{~b}$ & 0.1 & $1.8 \mathrm{a}$ & $0.1 \mathrm{~b}$ & 0.1 & $0.1 \mathrm{c}$ & $13.7 \mathrm{a}$ & $2.6 \mathrm{~b}$ & $17.7 \mathrm{a}$ & $10.7 b$ & $110.3 \mathrm{e}$ \\
\hline 'Camarosa' & $1.2 \mathrm{a}$ & 0.1 & $1.8 \mathrm{a}$ & $0.1 \mathrm{~b}$ & 0.1 & $0.1 \mathrm{a}$ & $8.1 \mathrm{c}$ & $3.4 \mathrm{a}$ & $8.3 \mathrm{~d}$ & $10.5 b$ & $155.6 \mathrm{a}$ \\
\hline CV (\%) & 2.1 & 6.5 & 9.5 & 5.1 & 7.9 & 5.1 & 2.0 & 5.7 & 1.6 & 2.0 & 9.2 \\
\hline 'Camino Real' & $2.2 \mathrm{a}$ & $0.2 \mathrm{a}$ & $1.3 \mathrm{c}$ & $1.5 \mathrm{~b}$ & $0.3^{\mathrm{ns}}$ & $0.1^{\mathrm{ns}}$ & $24.8 b$ & $5.0^{\mathrm{ns}}$ & $18.0^{\mathrm{ns}}$ & $16.0^{\mathrm{ns}}$ & $126.0 \mathrm{c}$ \\
\hline 'Festival' & $2.4 \mathrm{a}$ & $0.2 \mathrm{a}$ & $1.6 \mathrm{~b}$ & $1.9 \mathrm{a}$ & 0.3 & 0.1 & $34.8 \mathrm{a}$ & 5.0 & 23.0 & 38.0 & $346.0 \mathrm{a}$ \\
\hline 'Oso Grande' & $1.6 \mathrm{~b}$ & $0.1 \mathrm{~b}$ & $1.8 \mathrm{a}$ & $1.5 \mathrm{~b}$ & 0.3 & 0.1 & $33.3 \mathrm{a}$ & 5.0 & 20.0 & 23.0 & $424.0 \mathrm{a}$ \\
\hline ‘Álbion’ & $1.8 \mathrm{~b}$ & $0.2 \mathrm{a}$ & $1.7 \mathrm{ab}$ & $1.8 \mathrm{a}$ & 0.3 & 0.1 & $31.2 \mathrm{a}$ & 4.0 & 35.0 & 20.0 & $389.0 \mathrm{ab}$ \\
\hline 'Camarosa' & $1.8 \mathrm{~b}$ & $0.1 b$ & $1.8 \mathrm{a}$ & $1.3 \mathrm{c}$ & 0.3 & 0.1 & $24.4 \mathrm{~b}$ & 5.0 & 37.0 & 17.0 & $199.0 \mathrm{~b}$ \\
\hline CV (\%) & 9.0 & 7.3 & 8.4 & 4.7 & 9.0 & 3.4 & 16.4 & 7.4 & 11.6 & 13.2 & 8.7 \\
\hline
\end{tabular}

${ }^{(1)}$ Means followed by the same letter in the column do not differ by the Scott-Knott test $(\mathrm{P} \leq 0.05)$. ns - not significant. 
Table 4 - Reproduction factor of Meloidogyne hapla, reaction regarding the susceptibility $(\mathrm{S})$ or resistance $(\mathrm{R})$ of Meloidogyne hapla and incidence of Botrytis cinerea fruit strawberry cultivars in southern Minas Gerais states.

\begin{tabular}{llcc}
\hline Cultivar & $\begin{array}{c}\text { Reproduction } \\
\text { factor }\end{array}$ & Reaction & $\begin{array}{c}\text { Incidence of } \\
\text { Botrytis } \\
\text { cinerea }\end{array}$ \\
\hline 'Camino Real' & 87.7 & $\mathrm{~S}$ & $26.6 \mathrm{~b}$ \\
'Festival' & 86.2 & $\mathrm{~S}$ & $12.3 \mathrm{c}$ \\
'Oso Grande' & 0.3 & $\mathrm{R}$ & $43.3 \mathrm{a}$ \\
'Albion' & 0.7 & $\mathrm{R}$ & $16.6 \mathrm{c}$ \\
'Camarosa' & 1.8 & $\mathrm{~S}$ & $20.0 \mathrm{bc}$ \\
CV (\%) & 17.3 & - & 19.5 \\
\hline
\end{tabular}

${ }^{(1)}$ Means followed by the same letter in the column do not differ by the Scott-Knott test $(\mathrm{P} \leq 0.05)$.

associated with the "redness", using the example of 'Oso Grande' and 'Albion' cultivars.

The 'Oso Grande' cultivar showed high fruit production (Table 1), absence of "redness" in the ratings field (Table 2) and resistance to nematode Meloidogyne hapla (Table 4). However, in the vessels containing plants of this cultivar that were inoculated with the nematode, it was observed the "redness" (Table 5).

Despite the 'Albion' cultivar present average fruit production (Table 1), there was no "redness" in the ratings field (Table 2) and resistance to nematode Meloidogyne hapla (Table 4). In plants in vessels, there were no "redness" symptoms in this cultivar, independent from those that were inoculated with nematode or not (Table 5).

As to Botrytis cinerea, 'Oso Grande' cultivar showed a higher incidence (43.33\%) (Table 4). This fact may be related by lower fruit firmness and high content of soluble solids in this cultivar (Table 1), which led to increased Botrytis cinerea incidence. According to MAZARO et al. (2008), strawberries are highly perishable fruits after harvesting, but this is made worse by rot, especially when this is caused by Botrytis cinerea.

\section{CONCLUSION}

Cultivars presented differences in fruit production and also in the incidence of "redness". The lowest performance in production was related to the high incidence of the nematode Meloidogyne hapla. 'Oso Grande' and 'Albion' presented nematode-resistant behavior. It was possible to find a relationship between the incidence of the Meloidogyne hapla nematode, and the incidence of "redness" only in "Camino Real' cultivar.

Table 5 - Final fresh mass of the root (g), quantity of Meloidogyne hapla eggs in roots, incidence of "redness" with inculation of Meloidogyne hapla or not, in strawberry cultivars in pots.

\begin{tabular}{|c|c|c|c|c|}
\hline Cultivar & Inculation & Mass of the root $(\mathrm{g})^{(1)}$ & Quantity of eggs ${ }^{(1)}$ & Incidence of "redness" \\
\hline \multirow{2}{*}{ 'Camino Real' } & Without & $58.8 \mathrm{a}$ & $3,549.3 b$ & Absence \\
\hline & With & $41.2 \mathrm{~b}$ & $135,700.0 \mathrm{a}$ & Presence \\
\hline \multirow{2}{*}{ 'Festival' } & Without & $57.0 \mathrm{a}$ & $4,108.6 \mathrm{a}$ & Absence \\
\hline & With & $18.8 \mathrm{~b}$ & $2,901.3 \mathrm{a}$ & Presence \\
\hline \multirow{2}{*}{ 'Oso Grande' } & Without & $30.9 \mathrm{a}$ & $2,370.6 b$ & Absence \\
\hline & With & $19.1 b$ & $44,148.6 \mathrm{a}$ & Presence \\
\hline \multirow{2}{*}{ 'Albion' } & Without & $44.1 \mathrm{a}$ & $13,643.3 b$ & Absence \\
\hline & With & $27.2 b$ & $58,881.3 \mathrm{a}$ & Absence \\
\hline \multirow{2}{*}{ 'Camarosa' } & Without & $55.7 \mathrm{a}$ & $377.3 b$ & Absence \\
\hline & With & $25.8 \mathrm{~b}$ & $187,557.3 \mathrm{a}$ & Presence \\
\hline $\mathrm{CV}(\%)$ & - & 24.4 & 10.2 & - \\
\hline
\end{tabular}

${ }^{(1)}$ Means followed by the same letter in the column do not differ by the Scott-Knott test $(\mathrm{P} \leq 0.05)$. 


\section{REFERENCES}

ANTUNES, M.C. et al. Postharvest quality of strawberry produced during two consecutive seasons. Horticultura Brasileira, v.32, n.2, p.168-173,Apr./Jun. 2014. Available from: $<$ http://www.scielo. br/scielo.php?pid=S0102-05362014000200168\&script $=$ sci arttext $>$. Accessed: Apr. 01, 2015. doi: 10.1590/S010205362014000200008 .

CAPRONI, C.M. et al. Produção sustentável de morangueiro. Revista Agrogeoambiental, v.5, n.3, p.91-98, Dec. 2013. Available from: <http://agrogeoambiental.ifsuldeminas.edu.br/ index.php/Agrogeoambiental/article/view/545/544>. Accessed: Apr. 22, 2015

COCCO, C. et al. Strawberry yield submitted to different root pruning intensities of transplants. Revista Brasileira de Fruticultura, v.34, n.4, p.1284-1288, Dec. 2012. Available from: $\quad<$ http://www.scielo.br/scielo.php?script=sci_arttext\&pid $=$ S0100-29452012000400039>. Accessed: Mar. 23, 2015. doi: $10.1590 / \mathrm{S} 0100-29452012000400039$.

HENZ, G.P. Desafios enfrentados por agricultores familiares na produção de morango no Distrito Federal. Horticultura Brasileira, v.28, n.3, p.260-265, Jul./Sep. 2010. Available from: $\quad<\mathrm{http}: / /$ www.scielo.br/scielo.php?script=sci_arttext\&pid $=$ S0102-05362010000300003 $>$. Accessed: Mar. 12, 2015. doi: $10.1590 / \mathrm{S} 0102-05362010000300003$.

MAZARO, S.M. et al. Comportamento pós-colheita de frutos de morangueiro após a aplicação pré-colheita de quitosana e acibenzolar-s-metil. Revista Brasileira de Fruticultura, v.30, n.1, p.185-190, Mar. 2008. Available from: $<$ http://www.scielo.
br/scielo.php?pid=S0100-29452008000100034\&script $=$ sci abstract\&tlng=pt $>$. Accessed: Apr. 22, 2015. doi: 10.1590/ S0100-29452008000100034.

MIRANDA, F.R. et al. Production of strawberry cultivars in closed hydroponic systems and coconut fibre substrate. Revista Ciência Agronômica, v.45, n.4, p.833-841, Oct./Dec. 2014. Available from: $<$ http://www.scielo.br/pdf/rca/v45n4/22.pdf>. Accessed: Feb. 27, 2015.

NUNES, C.F. et al. The genetic diversity of strawberry (Fragaria ananassa Duch.) hybrids based on ISSR markers. Acta Scientiarum. Agronomy, v.35, n.4, p.443-452, Oct. 2013. Available from: <http://periodicos.uem.br/ojs/index.php/ ActaSciAgron/article/view/16737>. Accessed: Mar. 10, 2015. doi: 10.4025/actasciagron.v35i4.16737.

NYOIKE, T.W. et al. Confirmation of Meloidogyne hapla on strawberry in Florida using molecular and morphological techniques. Nematropica, v.42, n.2, p.253-259, Dec. 2012. Available from: <http://journals.fcla.edu/nematropica/article/ view/81857/78980>. Accessed: Mar. 21, 2015.

PINHEIRO, J.B. et al. Reação de genótipos de Capsicum ao nematóide-das-galhas. Horticultura Brasileira, v.32, n.3, p.371-375, Jul./Sep. 2014. Available from: $<$ http://www.scielo. br/scielo.php?pid=S0102-05362014000300371\&script $=$ sci arttext $>$. Accessed: Mar. 12, 2015. doi: 10.1590/S010205362014000300022 .

RODAS, C.L. Deficiências nutricionais do morangueiro: caracterização de sintomas visuais, produção e nutrição mineral. 2008. 86f. Dissertação (Mestrado Ciências dos Solos) Universidade Federal de Lavras, MG. 